\title{
Article \\ The ENRICH Marital Satisfaction (EMS) Scale: A Psychometric Study in a Sample of Portuguese Parents
}

\author{
Cristina Nunes ${ }^{1, *(\mathbb{D}}$, Cátia Martins ${ }^{1}\left(\mathbb{D}\right.$, Andreia Leal ${ }^{1}$, Pedro Pechorro ${ }^{2} \mathbb{D}$, Laura Inês Ferreira ${ }^{1}(\mathbb{D})$ \\ and Lara Ayala-Nunes ${ }^{3}$
}

check for updates

Citation: Nunes, Cristina, Cátia

Martins, Andreia Leal, Pedro

Pechorro, Laura Inês Ferreira, and

Lara Ayala-Nunes. 2022. The

ENRICH Marital Satisfaction (EMS)

Scale: A Psychometric Study in a

Sample of Portuguese Parents. Social

Sciences 11: 107. https://doi.org/

10.3390/socsci11030107

Academic Editor: Nancy Luke

Received: 19 November 2021

Accepted: 2 March 2022

Published: 4 March 2022

Publisher's Note: MDPI stays neutral with regard to jurisdictional claims in published maps and institutional affiliations.

Copyright: (C) 2022 by the authors. Licensee MDPI, Basel, Switzerland. This article is an open access article distributed under the terms and conditions of the Creative Commons Attribution (CC BY) license (https:// creativecommons.org/licenses/by/ $4.0 /)$
1 Psychology Research Centre, Campus de Gambelas, University of Algarve, 8005-139 Faro, Portugal; csmartins@ualg.pt (C.M.); a27822@ualg.pt (A.L.); liferreira@ualg.pt (L.I.F.)

2 School of Psychology, Campus de Gualtar, University of Minho, 4710-057 Braga, Portugal; ppechorro@gmail.com

3 Department of Psychiatry, University of Oxford, Warneford Hospital, Oxford OX3 7JX, UK; lara.ayalanunes@psych.ox.ac.uk

* Correspondence: csnunes@ualg.pt

\begin{abstract}
Marital satisfaction is a key construct in the assessment of a couple's relationship, and it encompasses aspects such as the feelings of affection, trust, and companionship that arise from the exchanges between spouses. The ENRICH Marital Satisfaction (EMS) Scale has been widely used as a reliable measure to assess marital satisfaction. In the present study, we aimed to analyze the psychometric properties and the factor structure of the EMS Scale in a sample of Portuguese parents. A total of 205 mothers and fathers participated; 107 were women (52\%), and 98 were men $(48 \%)$, and the mean age was 38.39 years $(S D=5.85)$. The majority were two-parent families $(89.3 \%)$, with children between the ages of 1 and 13 years $(M=6.90), 53 \%$ of whom were boys. The participants completed the EMS Scale together with the Parenting Stress Index Short Form and the Parenting Alliance Inventory. The results from a confirmatory factor analysis corroborate the two-dimensional structure of the instrument, with internal validity and reliability values that were suitable for application in the Portuguese population. The EMS Scale can be an important resource, with good psychometric quality, for professionals and researchers, which can be used in assessment and intervention programs, both at the individual and couple levels.
\end{abstract}

Keywords: confirmatory factor analysis; marital satisfaction; parenting alliance; parenting stress; psychometric study

\section{Introduction}

Marital satisfaction is a subjective construct that is widely used, alongside marital quality, success, and adjustment, to evaluate the relationship between partners (e.g., Tavakol et al. 2017). It is described as a set of feelings and sensations that include warmth, safety, and well-being, and as the expectations about the exchanges that exist in that type of relationship (Norgren et al. 2004). The way that couples organize their family and professional responsibilities, and the existence of good communication, are important aspects to consider in their marital adaptation and satisfaction, since the tensions between these two scenarios may impair their assessment of the marital satisfaction (Martínez-Pampliega et al. 2019). Thus, these are activities that are inherent to a couple's life, and that require complicity in interests, the establishment of rules, and the development of relational patterns (Tavakol et al. 2017).

Marital satisfaction levels tend to vary throughout the couple's life cycle, and they can be represented in a U-shaped model that starts out high in the early years of the relationship (1-3 years), and then declines in the intervening years as a result of the effort exerted by parenting (5-7 years), and, after this, reaches high values again when the children leave the home, with the subsequent changes in conjugality, where the couple returns to spending 
more time together (Pérez and Estrada 2006; Stephen and Raj 2014). According to Whisman (2019), marital satisfaction can be assessed on the basis of intra- and interpersonal factors, contextual factors, and their interrelationships. The personality features, cognitions, and emotional patterns of each subject can partly influence the assessment of the relationship satisfaction. Along with these, the factors that are associated with interpersonal relationships (i.e., sexual satisfaction), communication styles (i.e., expressions of feelings of intimacy, love, and problems), conflict resolution, stressful life events, and similarities between partners take on relevant significance (Whisman 2019).

The health of the partners may also be affected (e.g., Cao et al. 2017), and particularly their mental health (Whisman et al. 2021). Having a satisfying marriage results in greater flexibility in the management of life's pressures, a lower risk of psychopathology, better adjustment, greater longevity (Whisman et al. 2018), and fewer health problems (Vest et al. 2017). Marital satisfaction is also a good predictor of adjustment in the elderly (Santos et al. 2020), and it is a predictor of well-being and quality of life in later adulthood (e.g., Norgren et al. 2004).

Marital satisfaction affects the health of children (e.g., Cummings and Davies 2010), and it may be a risk factor for their adjustment (Knopp et al. 2017). The presence of conflict within the family can have different effects on the child. Destructive conflict (which is characterized by hostility, anger, and aggression) can weaken the child's safety levels, so that the child will feel fearful and worried about the stability of his/her family, while constructive conflict (which uses warmth and problem-solving strategies, and that compromises during conflict) can strengthen the child's safety levels and perceptions about the family stability (Koss et al. 2011). Moreover, investigations have shown that frequent conflict and low marital satisfaction could evoke increased emotional and behavioral problems in children (e.g., Frankel et al. 2015), as well as lower levels of academic achievement (Timmons and Margolin 2015).

The existence of repeated and intense marital conflicts that are unresolved with positive practices becomes a risk factor for children (Cutrín et al. 2019; Fariña et al. 2020; Gómez-Ortiz et al. 2019; Gallego et al. 2019) and may have consequences in terms of their psychological adjustment (Camisasca et al. 2019), which could lead to externalization problems, such as violence, antisocial behavior, or a poor school performance. On the other hand, it can also be reflected in internalization, with high levels of psychological distress, low self-esteem, or a depressive symptomatology (Gómez-Ortiz et al. 2019; Martínez-Pampliega et al. 2019). Even if the couple has conflicts, parenting requires that the caregivers coordinate their goals, styles, and strategies towards their children (Grych 2002), which implies good communication, cooperation, and conflict management (Ayala-Nunes et al. 2013). The existence of good levels of parental alliance, which is defined as how the parents appreciate, respect, and value the opinions of their spouses with regard to parenting (Abidin and Brunner 1995), is related to high levels of marital support. Likewise, low marital satisfaction has been associated with inadequate maternal behavior, lower maternal sensitivity, and to an insecure and disorganized mother-child attachment (Finger et al. 2009).

Thus, we can consider the marital satisfaction level as an indicator of the parenting relationship level: partners with higher levels of marital satisfaction tend to have higher parenting sensitivity (Cummings and Davies 2010), higher parental satisfaction, and more responsive parenting practices (e.g., Hou et al. 2019), compared to couples who have lower levels of satisfaction in their relationships (Knopp et al. 2017). Moreover, the higher the levels of marital satisfaction, the lower the rates of parental stress, especially when parents have children with several behavioral problems (e.g., Robinson and Neece 2015).

Marital satisfaction is, therefore, a relevant dimension in the parental ecology, and it is useful both for the study of the family system, and for assessing the support and intervention needs, which requires researchers and professionals to have valid reliable instruments that are adapted to the Portuguese population. The assessment of marital satisfaction becomes even more relevant in families with children because marital satis- 
faction is a determinant of parenting, and it may act as a protective factor, according to Belsky's (1984) proposed ecological model.

The present study will analyze the psychometric properties of the EMS Scale with a sample of Portuguese parents. In Portugal, there is a need for short, valid, and reliable scales that measure marital satisfaction. The number of divorces in Portugal has increased in the last decades, which converges with the number of marriages. The divorce rate for every 100 marriages in 2019 was 61.4. With regard to blended families, the available data are less recent, but they show that they represented 8.12\% (PORDATA 2021).

There are several instruments that are used to measure marital satisfaction, such as the Marital Adjustment Test (MAT) (Locke and Wallace 1959), the Dyadic Adjustment Scale (DAS) (Spanier 1976), the Couple Satisfaction Index (CSI) (Funk and Rogge 2007), and the ENRICH (Enriching and Nurturing Relationship Issues, Communication and Happiness) Marital Satisfaction (EMS) Scale (Fowers and Olson 1989, 1993).

In the Portuguese context, we found some validations of the instruments that are used to assess marital satisfaction, such as the Marital Satisfaction Scale (MSC) (Weiss and Palos 1988, Brazilian version by (Coleta 1989)), which includes three dimensions: the satisfaction with the partner's emotional aspects, the satisfaction with the marital interaction, and the satisfaction with the structural aspects (Hernandez et al. 2017); the Marital Satisfaction Index (Hudson 1992, Portuguese adaptation by (Pereira et al. 2000)), which evaluates the degree of the severity/magnitude of the couple's problems in a marital relationship; the Kansas Marital Satisfaction Scale (Schumm et al. 1986; Portuguese version by (Antunes et al. 2014)), which measures the satisfaction with the partner, the marriage, and the couple relationship; the Revised Dyadic Adjustment Scale (R-DAS) (Spanier 1976; Portuguese version by (Pereira 2003)), which focuses on the assessment of the marital adjustment, namely, the consensus, satisfaction, and cohesion; the Love Scale (an adaptation of the Marriage and Relationship Questionnaire; Russel and Wells 1986; Brazilian version by (França et al. 2016)); or the Evaluation Scale of Marital Areas Satisfaction-(ESAVIC) (Narciso and Costa 1996), which assesses 10 areas of marital life (i.e., leisure time, autonomy, sexuality, family functions, communication and conflicts, feelings, emotional intimacy, relationship continuity, physical and psychological characteristics, and extrafamilial relationships).

The ENRICH Marital Satisfaction (EMS) Scale (Fowers and Olson 1993) originated from the ENRICH Inventory (Fowers and Olson 1989), which is a questionnaire that is composed of 125 items with 14 scales (i.e., idealistic distortion, marital satisfaction, personality aspects, communication, conflict resolution, financial management, leisure activities, the sexual relationship, children and parenting, family and friends, equative roles, religious orientation, marital cohesion, and marital adjustment). The length of the questionnaire has been pointed out as a limitation of its use. Thus, Fowers and Olson (1993) developed a brief version, which is easy and quick to apply (Ferrão et al. 2019), and, nowadays, we can find several versions with smaller numbers of items, such as 47 items (e.g., Soleimanian 1994), 35 items (Alidoosti et al. 2011; Asoodeh et al. 2011), 15 items (Fowers and Olson 1993), and 10 items (e.g., Escribà-Agüir and Artazcoz 2011). The difference between the last two versions is related to the use of the Idealistic Distortion Scale (5 items), a dimension that was developed to control for the social desirability in the assessment of the marital relationship satisfaction (i.e., to overcome the propensity to evaluate the marital relationship in an unrealistically positive way). There have been studies with the 10-item version that do not use the Idealistic Distortion Scale (e.g., Arab Alidousti et al. 2015; Escribà-Agüir and Artazcoz 2011).

The present study focuses on the shortened version of the EMS Scale (i.e., 15 items; Fowers and Olson 1993), which is used to evaluate the satisfaction that is felt in a marital relationship through two dimensions: the marital satisfaction (MS) (10 items), which assesses several aspects that are inherent to the marital relationship; and idealistic distortion (ID) (5 items). This instrument has been translated in various countries, such as Brazil (10 items; Ferrão et al. 2019); China (10 items; Li 1999); Spain (10 items; Escribà-Agüir and Artazcoz 2011); India (Pandya 2019); Iran (10 items; Arab Alidousti et al. 2015); and 
Japan (10 items; Suzuki 2010), with mainly samples of adults from the general populations. In Portugal, Marques (2001) adapted the full version of this instrument, but there are no validated studies of this brief version of the EMS Scale.

In the Brazilian version, in which only the positive dimension of marital satisfaction (10 items) was considered, the psychometric validity obtained two factors (Factor 1 explained $72 \%$, and Factor 2 explained 10\%), but the reliability values supported the single-factor solution that was adopted, with good adjustment (Cronbach's alpha of 0.80 for men, and 0.78 for women). Ferrão et al. (2019) relate the marital satisfaction to general satisfaction and perceived stress scales, and they obtained a high correlation with the satisfaction, and a moderate association with the perceived stress. As for the Indian version, this was not examined psychometrically, but a satisfactory Cronbach's alpha was reported $(\alpha=0.93$; Pandya 2019).

Considering that the brief version of the EMS Scale could be very useful to include in the assessment protocols for the analysis of the family functioning, this study aimed to analyze the psychometric properties of the EMS Scale, and to verify if the factorial structure replicates the original one. As for our predictions, we expected that the Portuguese version would demonstrate: (1) A two-dimensional structure; with (2) Acceptable internal consistency; and (3) Construct validity with regard to the measures of parental alliance and parental stress.

\section{Materials and Methods}

\subsection{Participants}

The participants included 205 parents that were living in Algarve (the south of Portugal). Most of them were mothers ( $52 \%)$, and their average age was 37.54 years $(S D=5.69$; range: $23-49$ years). The fathers $(48 \%)$ were aged between 26 and 53 years $(M=39.31$; $S D=5.90)$. On average, they had 1.69 children $(S D=0.79$; range: $1-7$ years), $53 \%$ of whom were boys, and $47 \%$ of whom were girls, with an average of 6.90 years $(S D=3.19$; range: $1-13$ years).

With regard to the educational levels, $42.0 \%$ of the participants had completed high school, $28.3 \%$ had completed university studies, $19.5 \%$ had completed compulsory education, and $10.2 \%$ had not completed compulsory education. Most of the families were nuclear, with two parents $(89.3 \%)$, with only $4.9 \%$ single-parent and $5.9 \%$ restructured families.

\subsection{Instruments}

The ENRICH Marital Satisfaction (EMS) Scale (Fowers and Olson 1993), as described above, is composed of 15 items, which are answered on a five-point scale (between $1=$ Strongly Disagree, and $5=$ Strongly Agree), and includes two dimensions: marital satisfaction (MS) (e.g., "I am not happy about our communication and feel my partner

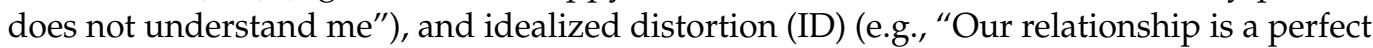
success"). The scale scoring is carried out by summing up the items, and by reversing the values of Items $2,5,8,9,12$, and 14 . The total score of the scale is calculated by using the following formula: EMS $=$ MS $-\left[(\mathrm{MS}) \times(\text { correlation between MS and ID })^{2} \times(\mathrm{ID} \times 0.01)\right]$. The higher scores represent higher levels of marital satisfaction.

The Parenting Stress Index Short Form (PSI-SF) (Abidin 1995; Portuguese version by Santos 2008) is a self-report questionnaire that assesses the level of parenting stress that is perceived by the parents, and it can only be applied to parents with children up to 13 years of age. It consists of 36 items, and it uses a five-point scale ( $1=$ Strongly Disagree, to $5=$ Strongly Agree), which is subdivided into three subscales: parental distress (PD) ("I feel trapped by my responsibilities as a parent"; $\alpha=0.89$ ); the parent-child dysfunctional interaction (PCDI) ("My child smiles at me much less than I expected"; $\alpha=0.80$ ); and the degree to which the parent evaluates their child as a difficult child (DC) ("My child gets upset easily over the smallest thing"; $\alpha=0.75$ ). The higher scores show greater levels of stress in parenting. 
The Parenting Alliance Inventory (PAI) (Abidin and Brunner 1995; Portuguese version by (Nunes et al. 2021)) is a one-dimensional scale that measures the extent to which one parent believes that he/she has a good, supportive, trusting, and functional relationship with the other parent (e.g., "When there is a problem with our child, we work out a good solution together"). It consists of 20 items that are answered on a five-point scale (from $1=$ Strongly Disagree, to $5=$ Strongly Agree). In the present study, it presents a Cronbach's alpha of 0.95 , which demonstrates excellent reliability. The PAI can be applied regardless of the parents' current marital status or the parental figure's biological relationship to the child. The higher scores indicate greater perceived support among the spouses.

An ad hoc sociodemographic questionnaire was applied in order to obtain data about the participants' age, sex, socioeconomic status, and years of schooling completed.

\subsection{Procedures}

First, authorization was requested from the authors of the ENRICH Scale for the translation and validation of the instrument in Portugal. The initial translation from English into Portuguese was completed by the first and second authors of this paper, which ensured the correct understanding of the meaning of the items. The questionnaire was then independently back-translated into English by a native English speaker with considerable professional experience in translating psychology-related scientific texts. The cultural adaptation was particularly considered, and it took into account the clarity, common language use, and conceptual equivalence of the scale.

The participants were recruited using a snowball strategy. Using a snowball sampling technique, master's students from the Department of Psychology of the University of Algarve were contacted and were asked to participate as intermediates by recruiting five parents each to answer the EMS Scale, the PAI, and the PSI-SF. The questionnaires were applied to fathers and/or mothers who met the following inclusion criteria: (1) Parents who had at least one child aged up to the age of 13 years old; and (2) Parents with no known psychosocial risks. All of the participants signed written informed consent documents and were informed about the aims of the study, the noncompensatory nature of their participation, the anonymous and confidential nature of their responses, and the possibility of withdrawing from the study at any time, without any consequences. The study was approved by the University of Algarve.

\subsection{Analysis Plan}

The data were analyzed using SPSS v25 software. The analysis of the EMS factor structure was performed using EQS 6.3 software (Bentler and Wu 2015), with the estimation performed by maximum likelihood (ML) robust methods. The goodness-of-fit indices were obtained by calculating the Satorra-Bentler chi-squared/degrees of freedom, the CFI (the Comparative Fit Index), the IFI (the Incremental Fit Index), the RMSEA (the Root Mean Square Error of Approximation), and the NNFI (the Non-Normed Fit Index). CFI values $\geq 0.90$ and RMSEA values $<0.08$ were considered to be the indicators of an adequate adjustment; NNFI and CFI values $\geq 0.95$ and RMSEA values $\leq 0.06$ indicate good fit, and an IFI value $\geq 0.90$ was considered acceptable (Byrne 2006). The CFA was performed directly on the items, and it retained the factors with factor loadings $\geq 0.45$.

An ANOVA was used for the group comparisons, and Pearson's correlations were used to examine the associations between the scale variables (Knapp 2017). The correlations were considered low if they were below 0.20 , they were considered moderate if they were between 0.20 and 0.50 , and they were considered high if they were above 0.50 . The Cronbach' alphas were considered good if they were above 0.70 , and the corrected item-total correlations were considered adequate if they were above 0.20 (Tabachnick et al. 2019). 


\section{Results}

\subsection{Descriptive Analysis}

Overall, the participants reported high levels of marital satisfaction $(M=33.69$, $S D=4.93 ; \operatorname{Min}=17.37, \operatorname{Max}=43.07$; Table 1). The skewness $(-0.76)$ and kurtosis (1.05) indices did not deviate much from normality $(S k<3$, and $K u<10)$. The EMS had a good internal consistency $(\alpha=0.87)$, and the correlations between each item and the total value of the scale ranged between 0.25 and 0.70 . The Cronbach's alpha values did not show significant changes with the elimination of any of the items from the scale, except for Item $14(\alpha=0.88)$; thus, the contribution made by the 15 items was considered relevant, and we chose to keep the proposal that was initially formulated by the original authors (Fowers and Olson 1993).

Table 1. Descriptive analysis and discriminant capacities of the original items $(\mathrm{N}=205)$.

\begin{tabular}{|c|c|c|c|c|c|c|}
\hline & $M$ & $S D$ & $S$ & $K$ & $\begin{array}{l}\text { Corrected } \mathbf{r} \\
\text { Item Total }\end{array}$ & $\begin{array}{c}\alpha \text { If Item } \\
\text { Deleted }\end{array}$ \\
\hline Item 1 & 4.01 & 0.82 & -1.27 & 2.79 & 0.70 & 0.86 \\
\hline Item 2 inverted & 3.91 & 1.08 & -0.90 & -0.10 & 0.58 & 0.86 \\
\hline Item 3 & 4.09 & 0.87 & -1.32 & 2.39 & 0.64 & 0.86 \\
\hline Item 4 & 3.79 & 0.93 & -1.14 & 1.61 & 0.63 & 0.86 \\
\hline Item 5 inverted & 3.82 & 1.17 & -0.84 & -0.28 & 0.69 & 0.85 \\
\hline Item 6 & 3.65 & 1.01 & -0.76 & 0.14 & 0.59 & 0.86 \\
\hline Item 7 & 4.01 & 0.84 & -1.42 & 3.30 & 0.67 & 0.86 \\
\hline Item 8 inverted & 3.55 & 1.23 & -0.48 & -0.89 & 0.36 & 0.87 \\
\hline Item 9 inverted & 3.52 & 1.19 & -0.24 & -1.20 & 0.45 & 0.87 \\
\hline Item 10 & 3.62 & 0.97 & -0.76 & 0.35 & 0.56 & 0.86 \\
\hline Item 11 & 3.94 & 0.94 & -1.10 & 1.20 & 0.60 & 0.86 \\
\hline Item 12 inverted & 4.06 & 0.98 & -1.15 & 0.81 & 0.41 & 0.87 \\
\hline Item 13 & 4.10 & 0.97 & -1.11 & 0.77 & 0.44 & 0.87 \\
\hline Item 14 inverted & 3.75 & 1.21 & -0.87 & -0.23 & 0.24 & 0.88 \\
\hline Item 15 & 3.84 & 1.13 & -1.10 & 0.64 & 0.48 & 0.87 \\
\hline Total & 33.69 & 4.93 & -0.76 & 1.05 & - & 0.87 \\
\hline
\end{tabular}

\subsection{Factor-Structure Analysis}

Table 2 displays the goodness-of-fit indices of the three models that were tested by the CFA: the unifactorial model; the bifactorial model, with the structure of the original version; and a revised bifactorial model. In the revised model, for an adequate fit, Items 8,12 , and 14 were eliminated, and the intercorrelation errors between Items 2 and 5 were performed. Thus, the items that presented low loadings and low corrected item-total correlations were removed (Items 8: "I am unhappy about financial position and the way we make financial decisions"; 12: "I am not satisfied with the way we each handle our responsibilities as parents"; and 14: "I am dissatisfied about the relationship with my parents, in-laws, and/or friends", from the factor, marital satisfaction).The indices revealed a good adequacy of the revised two-factor model: $\mathrm{S}-\mathrm{B} \chi^{2} / \mathrm{gl}=1.95 ; \mathrm{IFI}=0.98 ; \mathrm{NNFI}=0.97$; $\mathrm{CFI}=0.98$; and RMSEA $=0.07$. With regard to the saturation values, most of the items showed correlations $>0.30$ (Table 3$)$.

Table 2. Goodness-of-fit indices for ML models of EMS Scale.

\begin{tabular}{lccccccc}
\hline \multicolumn{1}{c}{ EMS } & S-Bc ${ }^{2} / \mathbf{d f}$ & IFI & NNFI & CFI & RMSEA & CI (90\%) & AIC \\
\hline Unifactorial model & 4.38 & 0.87 & 0.85 & 0.87 & 0.13 & $0.12-0.14$ & 214.13 \\
Two-factor model & 4.43 & 0.87 & 0.85 & 0.87 & 0.13 & $0.12-0.14$ & 216.45 \\
Revised two-factor model (1) & 1.95 & 0.98 & 0.97 & 0.98 & 0.07 & $0.05-0.09$ & -2.40 \\
\hline
\end{tabular}

$\mathrm{ML}=$ maximum likelihood; S-Bc ${ }^{2}=$ Satorra-Bentler chi-square; $\mathrm{df}=$ degrees of freedom; IFI = Incremental Fit Index; NNFI = Non-Normed Fit Index; CFI = Comparative Fit Index; RMSEA = Root Mean Square Error of Approximation; $\mathrm{CI}=$ confidence interval, $\mathrm{AIC}=$ Akaike information criterion; (1) Items 8, 12, and 14 were removed as were Intercorrelation Error Items 2-5. 
Table 3. Standardized factor loadings of the revised two-factor model of the EMS Scale.

\begin{tabular}{lcc}
\hline \multicolumn{1}{c}{ EMS } & F1 (Satisfaction) & F2 (Distortion) \\
\hline Item 1 & 0.47 & 0.80 \\
Item 2 (inverted) & 0.77 & \\
Item 3 & & 0.79 \\
Item 4 & 0.63 & 0.76 \\
Item 5 (inverted) & 0.82 & 0.30 \\
Item 6 & & \\
Item 7 & 0.69 & \\
Item 9 (inverted) & 0.66 & 0.44 \\
Item 10 & & \\
Item 11 & 0.53 & \\
Item 13 & & \\
Item 15 & &
\end{tabular}

As for the means of the inter-item correlations, the results were adequate. The two subscales presented values above 0.20 , which reveals a good homogeneity of the items. The corrected item-total correlation range was acceptable $(>0.30)$. The internal consistency indices that were obtained were $\alpha=0.84$ for the satisfaction, and $\alpha=0.74$ for the distortion (Table 4).

Table 4. Internal consistencies of the EMS.

\begin{tabular}{lccccc}
\hline & $\boldsymbol{M}$ & SD & Alpha & MIIC & CITCR \\
\hline Satisfaction & 27.30 & 4.88 & 0.84 & 0.43 & $0.49-0.70$ \\
Distortion & 19.06 & 3.46 & 0.74 & 0.40 & $0.31-0.63$ \\
\hline
\end{tabular}

$\bar{M}=$ mean; $S D$ = standard deviation; Alpha = Cronbach's alpha; MIIC = mean inter-item correlation; CITCR = corrected item-total correlation range.

\subsection{Construct Validity Analysis}

Table 5 shows the associations between the EMS and the other dimensions of parental behavior: the Parenting Alliance Index (PAI) and the Parenting Stress Index (PSI). We observed an expected significant positive correlation with the PAI, and negative significant correlations with the PSI-SF PD and PCDI scales.

Table 5. Construct validity.

\begin{tabular}{lc}
\hline & EMS \\
\hline Parenting Alliance & $0.70^{* * *}$ \\
Parenting Distress & $-0.18^{*}$ \\
Parent-Child Dysfunctional Interaction & $-0.20^{* *}$ \\
Difficult Child & -0.10 \\
\hline
\end{tabular}

${ }^{*} p \leq 0.05,{ }^{* *} p \leq 0.01$, and ${ }^{* * *} p \leq 0.001$.

\section{Discussion}

This study aimed to analyze the psychometric properties of Fowers and Olson's ENRICH Marital Satisfaction Scale (EMS) in a sample of Portuguese parents, as well as the validity of this instrument with the measures of family functioning (convergent validity) and parental stress (divergent validity). The results that were obtained by using a confirmatory factor analysis, after testing three models (i.e., one-factor, two-factor, and revised two-factor models), support the assumption of using the EMS Scale for assessing marital satisfaction in the Portuguese population, and they confirm the two-dimensional structure of the scale. Thus, we found sustainability for the dimensions of marital satisfaction (7 items) and idealized distortion (5 items), which is congruent with the initial definition of Fowers and Olson's study (1993), and which allows us, on the one hand, to assess the couple's perception of each area of the marital relationship, and, on the other hand, to make 
an adjustment on the basis of the real feelings of the spouses towards their relationship. According to Fowers and Olson (1993), theoretically, one can have a positive assessment (i.e., no regrets about the marriage), as well as a perfect understanding about one's spouse, but it is unlikely that these feelings reflect reality, and, thus, marital satisfaction may have an idealized level of distortion that is associated with it, which is often ignored by more conventional scales.

With regard to the mean value of the inter-item correlations, as well as the corrected correlations, the data were found to be adequate and homogeneous; thus, all of the indicators support our initial hypothesis that the psychometric characteristics of the instrument would be maintained in its application to the Portuguese population, which is similar to other validations (Ferrão et al. 2019).

As for the discriminant validity with the measures of parental stress, the results indicate negative and significant relationships with the marital satisfaction, which is congruent with what was predicted (e.g., Hess 2008; Robinson and Neece 2015). As expected, the relationship between the EMS Scale and the PAI shows a significant and positive association, which is consistent with other research, which suggests that the level of the marital satisfaction may contribute to the development and maintenance of a strong parental alliance, in the same way that more unsatisfactory relationships may affect the child's development and may have negative consequences on the parenting (e.g., Belsky 1984; Feinberg 2002, 2003). In this Brazilian validation scale, it was possible to observe a negative correlation between the measures of the marital satisfaction and the perceived stress. These data raise questions with regard to how this construct may be related not only to the levels of parental stress, but also to the measures of the general stress. Thus, it is important to reflect on the effective relevance that the levels of the satisfaction in a relationship may have in the other areas of individual functioning (e.g., work-family interactions) that are likely to be influenced by the demands that a romantic relationship may imply (Andrade et al. 2017; Fellows et al. 2016).

The participants reported high values of marital satisfaction, which is congruent with other research (e.g., Hess 2008), and which reveals that couples generally make very positive evaluations about their relationships.

The present study aimed to contribute to the adaptation and validation of an instrument to assess marital satisfaction, which may be used in several family intervention scenarios, such as programs that involve individual and couple assessments, where the levels of the alliance and parental stress may be considered as a means of family strengthening and preservation. However, the limitations include the fact that this research only focused on families from the general population and did not perform any construct validity or temporal stability studies. Future research may take into account factors such as the differences between the sexes of the participants, the levels of education, and the ages of the spouses, as well as other factors that are associated more with children (e.g., age, behavior, health) and with characteristics of other contexts that are relevant to the couple (e.g., work and extended family).

\section{Conclusions}

The findings of this study demonstrate that the EMS Scale can be considered a quick and easy-to-use instrument to assess marital satisfaction, with reliability with regard to the marital satisfaction and the idealized distortion. It has proven to be an useful psychometric resource for professionals and researchers. The Portuguese version of the EMS Scale that is offered in this study is a useful tool for both researchers and practitioners who need to assess marital satisfaction, which is a relevant construct that can be used to understand the family context.

Author Contributions: Conceptualization, C.N., C.M., P.P. and L.A.-N.; Data curation, C.N., C.M., A.L. and L.A.-N.; Formal analysis, C.N. and P.P.; Funding acquisition, C.N. and C.M.; Investigation, C.N., A.L. and L.A.-N.; Methodology, C.N., P.P. and L.A.-N.; Project administration, C.N.; Resources, L.I.F.; Writing-original draft, C.N., C.M., A.L., L.I.F. and L.A.-N.; Writing-review \& editing, C.N., 
C.M., A.L., P.P., L.I.F. and L.A.-N. All authors have read and agreed to the published version of the manuscript.

Funding: This work was funded by national funds through the FCT—Fundação para a Ciência e a Tecnologia—as part the project: CIP—RefUIDB/PSI/04345/2020.

Institutional Review Board Statement: The study was conducted according to the guidelines of the Declaration of Helsinki and was approved by the Scientific Commission of the Psychology and Sciences Education Department, the University of Algarve, Reference No. 55-20/12/2017.

Informed Consent Statement: Written informed consent was obtained from all of the participants involved in the study.

Data Availability Statement: The data can be made available to consultation upon request to the corresponding author.

Conflicts of Interest: The authors declare no potential conflict of interest with respect to the research, authorship, and publication of this article. The funders had no role in the design of the study; in the collection, analyses, or interpretation of data; in the writing of the manuscript; or in the decision to publish the results.

\section{References}

Abidin, Richard R. 1995. Parenting Stress Index: Short Form (PSI-SF). Lutz: Psychological Assessment Resources.

Abidin, Richard R., and Jack F. Brunner. 1995. Development of a Parenting Alliance Inventory. Journal of Clinical Child Psychology 24: 31-40. [CrossRef]

Alidoosti, Masoumeh, Elahe Tavassoli, Masoumeh Delaram, Arash Najimi, and Gholamreza Sharifirad. 2011. The relationship between satisfaction and knowledge about family-doctor program in Shahr-e-Kord. Zahedan Journal of Research in Medical Sciences 13: 36-69.

Andrade, Alexsandro Luiz, Vicente Cassepp-Borges, Emílio Ferrer, and Rozzana Sánchez Aragón. 2017. Análises de Dados Diádicos: Um Exemplo a Partir Da Pesquisa Com Casais Dyadic Data Analysis: An Example from Couples Research. Trends in Psychology 25: 1571-88. Available online: http:/ / pepsic.bvsalud.org/pdf/tp/v25n4/v25n4a05.pdf (accessed on 17 November 2021).

Antunes, Natália, Rita Francisco, Marta Pedro, Maria Teresa Ribeiro, and Salomé Santos. 2014. Escala de Satisfação Conjugal de Kansas. Unpublished manuscript. Lisboa: Universidade de Lisboa.

Arab Alidousti, Alireza, Nouzar Nakhaee, and Narges Khanjani. 2015. Reliability and validity of the Persian versions of the ENRICH marital satisfaction (brief version) and Kansas Marital Satisfaction Scales. Health and Development Journal 4: 158-67.

Asoodeh, Mohammad Hosein, Manijeh Daneshpour, Shiva Khalili, Masoud Gholamali Lavasani, Mahbobe Abuali Shabani, and Iman Dadras. 2011. Iranian Successful Family Functioning: Communication. Procedia-Social and Behavioral Sciences 30: 367-71. [CrossRef]

Ayala-Nunes, Lara, Cristina Nunes, and Ida Lemos. 2013. Parenting Alliance among Mothers of Psychosocially At-Risk Families. Spatial and Organizational Dynamics Discussion Papers 2014-2. Faro: CIEO-Research Centre for Spatial and Organizational Dynamics, University of Algarve.

Belsky, Jay. 1984. The Determinants of Parenting: A Process Model. Child Development 55: 83-96. [CrossRef]

Bentler, Peter M., and Eric Wu. 2015. Supplement to EQS 6.3 for Windows User's Guide. Temple City: Multivariate Software, Inc.

Byrne, Barbara M. 2006. Structual Equation Modeling with AMOS: Basic Concepts, Applications, and Programming, 2nd ed. New York: Routledge Academic.

Camisasca, Elena, Sarah Miragoli, and Paola Di Blasio. 2019. Children's Triangulation during Inter-Parental Conflict: Which Role for Maternal and Paternal Parenting Stress? Journal of Child and Family Studies 28: 1623-34. [CrossRef]

Cao, Hongjian, Nan Zhou, Xiaoyi Fang, and Mark Fine. 2017. Marital Well-Being and Depression in Chinese Marriage: Going beyond Satisfaction and Ruling out Critical Confounders. Journal of Family Psychology 31: 775-84. [CrossRef]

Coleta, Marilia F. D. 1989. A medida da satisfação conjugal: Adaptação de uma escala. Psico 18: 90-112.

Cummings, E. Mark, and Patrick T. Davies. 2010. Marital Conflict and Children: An Emotional Security Perspective. New York: Guilford Press.

Cutrín, Olalla, Lorena Maneiro, Jorge Sobral, and José A. Gómez-Fraguela. 2019. Longitudinal Effects of Parenting Mediated by Deviant Peers on Violent and Non-Violent Antisocial Behaviour and Substance Use in Adolescence. European Journal of Psychology Applied to Legal Context 11: 23-33. [CrossRef]

Escribà-Agüir, Vicenta, and Lucía Artazcoz. 2011. Gender Differences in Postpartum Depression: A Longitudinal Cohort Study. Journal of Epidemiology and Community Health 65: 320-26. [CrossRef] [PubMed]

Fariña, Francisca, Ramón Arce, David Tomé, and Dolores Seijo. 2020. Validación Del Cuestionario Actitud Ante El Conflicto Parental: Autoinformada y Referenciada (ACPar). Revista Iberoamericana de Psicología y Salud 11: 1. [CrossRef]

Feinberg, Mark E. 2002. Coparenting and the Transition to Parenthood: A Framework for Prevention. Clinical Child and Family Psychology Review 5: 173-95. [CrossRef] [PubMed] 
Feinberg, Mark E. 2003. The Internal Structure and Ecological Context of Coparenting: A Framework for Research and Intervention. Parenting 3: 95-131. [CrossRef]

Fellows, Kaylene J., Hsin Yao Chiu, E. Jeffrey Hill, and Alan J. Hawkins. 2016. Work-Family Conflict and Couple Relationship Quality: A Meta-Analytic Study. Journal of Family and Economic Issues 37: 509-18. [CrossRef]

Ferrão, Lívia Fraga, Alexsandro Luiz De Andrade, and Fabio Camilo da Silva. 2019. Escala ENRICH de satisfação conjugal: Adaptação e evidências psicométricas iniciais no Brasil. Revista Psicologia Em Pesquisa 13: 128-46. [CrossRef]

Finger, Brent, Sidney L. Hans, Victor J. Bernstein, and Suzanne M. Cox. 2009. Parent relationship quality and infant-mother attachment. Attachment \& Human Development 11: 285-306. [CrossRef]

Fowers, Blaine J., and David H. Olson. 1989. ENRICH Marital Inventory: A Discriminant Validity and Cross-Validation Assessment. Journal of Marital and Family Therapy 15: 65-79. [CrossRef]

Fowers, Blaine J., and David H. Olson. 1993. ENRICH Marital Satisfaction Scale: A Brief Research and Clinical Tool. Journal of Family Psychology 7: 176-85. [CrossRef]

França, Priscilla Soares de, Jean Carlos Natividade, and Fívia de Araújo Lopes. 2016. Evidências de Validade da Versão Brasileira da Escala Amor do Marriage and Relationships Questionnaire (MARQ). Psico-USF 21: 233-44. [CrossRef]

Frankel, Leslie A., Tomo Umemura, Deborah Jacobvitz, and Nancy Hazen. 2015. Marital Conflict and Parental Responses to Infant Negative Emotions: Relations with Toddler Emotional Regulation. Infant Behavior and Development 40: 73-83. [CrossRef] [PubMed]

Funk, Janette L., and Ronald D. Rogge. 2007. Testing the Ruler with Item Response Theory: Increasing Precision of Measurement for Relationship Satisfaction with the Couples Satisfaction Index. Journal of Family Psychology 21: 572-83. [CrossRef] [PubMed]

Gallego, Raquel, Mercedes Novo, Francisca Fariña, and Ramón Arce. 2019. Child-to-Parent Violence and Parent-to-Child Violence: A Meta-Analytic Review. European Journal of Psychology Applied to Legal Context 11: 51-59. [CrossRef]

Gómez-Ortiz, Olga, Eva M. Romera, Rocío Jiménez-Castillejo, Rosario Ortega-Ruiz, and Luis Joaquín García-López. 2019. Parenting Practices and Adolescent Social Anxiety: A Direct or Indirect Relationship? International Journal of Clinical and Health Psychology 19: 124-33. [CrossRef] [PubMed]

Grych, John H. 2002. Marital relationships and parenting. In Handbook of Parenting, 2nd ed. Edited by Mark Bornstein. Erlbaum: Mahwah, vol. 4, pp. 203-25.

Hernandez, José Augusto E., Camila M. Ribeiro, Ana Lúcia N. Carvalho, Regina Coeli T. Fonseca, Rafhael F. Peçanha, and Eliane Mary O. Falcone. 2017. Revisão da Estrutura Fatorial da Escala de Satisfação Conjugal. Temas Em Psicologia 25: 1977-90. [CrossRef]

Hess, Jill. 2008. Marital Satisfaction and Parental Stress. Logan: Utah State University.

Hou, Yubo, Feng Jiang, and Xinrui Wang. 2019. Marital Commitment, Communication and Marital Satisfaction: An Analysis Based on Actor-Partner Interdependence Model. International Journal of Psychology 54: 369-76. [CrossRef]

Hudson, W. W. 1992. Index of Marital Satisfaction Tempe. Tempe: Walmyr Publishing Co.

Knapp, Herschel. 2017. Intermediate Statistics Using SPSS. Thousand Oaks: Sage Publications.

Knopp, Kayla, Galena K. Rhoades, Elizabeth S. Allen, Aleja Parsons, Lane L. Ritchie, Howard J. Markman, and Scott M. Stanley. 2017. Within- and Between-Family Associations of Marital Functioning and Child Well-Being. Journal of Marriage and Family 79: 451-61. [CrossRef]

Koss, Kalsea J., Melissa R. W. George, Kathleen N. Bergman, E. M. Cummings, Patrick T. Davies, and Dante Cicchetti. 2011. Understanding Children's Emotional Processes and Behavioral Strategies in the Context of Marital Conflict. Journal of Experimental Child Psychology 109: 336-52. [CrossRef]

Li, L. J. 1999. Olson marital inventory (ENRICH). In Rating Scales for Mental Health. Edited by X. D. Wang, X. L. Wang and H. Ma. Beijing: Chinese Mental Health Journal Publisher, pp. 153-58.

Locke, Harvey J., and Karl M. Wallace. 1959. Short Marital-Adjustment and Prediction Tests: Their Reliability and Validity. Marriage and Family Living 21: 251. [CrossRef]

Marques, Eduardo. 2001. Amor e Qualidade de Vida Conjugal: Aplicações Do Inventário ENRICH. Interacções 1: 79-107. Available online: http:/ / www.interacoes-ismt.com/index.php/revista/article/viewFile/18/19 (accessed on 17 November 2021).

Martínez-Pampliega, Ana, Itxaso Ugarte Elicegui, Laura Merino, and David Herrero Fernández. 2019. Conciliación familia-trabajo y sintomatología externalizante de los hijos e hijas: Papel mediador del clima familiar. Revista Iberoamericana de Psicologia y Salud 10: 27-36. [CrossRef]

Narciso, Isabel, and Maria Emília Costa. 1996. Amores satisfeitos, mas não perfeitos. Cadernos de Consulta Psicológica 12: 115-30.

Norgren, Maria de Betânia Paes, Rosane Mantilla de Souza, Florence Kaslow, Helga Hammerschmidt, and Shlomo A. Sharlin. 2004. Satisfação Conjugal Em Casamentos de Longa Duração: Uma Construção Possível. Estudos de Psicologia (Natal) 9: 575-84. [CrossRef]

Nunes, Cristina, Lara Ayala-Nunes, Cátia Martins, Pedro Pechorro, and Laura Inês Ferreira. 2021. Parenting Alliance Inventory: Psychometric properties and invariance among a community and at-risk sample of Portuguese parents. Journal of Child and Family Studies 30: 3095-104. [CrossRef]

Pandya, Samta P. 2019. Marital Satisfaction of Highly Qualified Professionally Achieving Women Post-Retirement: The Urban Indian Scenario. Journal of Family Studies 25: 61-78. [CrossRef]

Pereira, Maria G. 2003. Revised Dyadic Adjustment Scale-Versão de Investigação. Braga: Universidade do Minho.

Pereira, Maria G., V. Ramalho, and P. Dias. 2000. Inventário de Satisfação Marital: Versão de investigação. Braga: Universidade do Minho. 
Pérez, Isabel, and Sinuhé Estrada. 2006. Intimidad y comunicación en cuatro etapas de la vida de pareja: Su relación con la satisfacción marital. Archivos Hispanoamericanos de Sexología 12: 133-63.

PORDATA. 2021. Estatísticas de divórcios e separação de pessoas e bens [Divorce Statistics and Separation of People and Property]. Available online: https://www.pordata.pt/DB/Portugal/Ambiente+de+Consulta/Tabela (accessed on 17 November 2021).

Robinson, Merideth, and Cameron L. Neece. 2015. Marital Satisfaction, Parental Stress, and Child Behavior Problems among Parents of Young Children with Developmental Delays. Journal of Mental Health Research in Intellectual Disabilities 8: 23-46. [CrossRef]

Santos, S. V. 2008. Forma Reduzida do Parenting Stress Index (PSI): Estudo Preliminar. In Programa e Resumos da Conferência Internacional Avaliação Psicológica: Formas e Contextos. Braga: Universidade do Minho.

Santos, Inês, Sofia von Humboldt, and Isabel Leal. 2020. O Efeito Da Imagem Corporal e Da Satisfação Conjugal No Ajustamento Ao Envelhecimento Dos Idosos. Psicologia, Saúde E Doença 21: 111-16. [CrossRef]

Schumm, Walter R., Lois A. Paff-Bergen, Ruth C. Hatch, Felix C. Obiorah, Janette M. Copeland, Lori D. Meens, and Margaret A Bugaighis. 1986. Concurrent and Discriminant Validity of the Kansas Marital Satisfaction Scale. Journal of Marriage and the Family 48: 381. [CrossRef]

Soleimanian, A. 1994. Survey Effect of Illogical Thinking (Cognitive Theory) in Marital Satisfaction. Master's thesis, Tarbiat Moalem University, Tehran, Iran.

Spanier, Graham B. 1976. Measuring Dyadic Adjustment: New Scales for Assessing the Quality of Marriage and Similar Dyads. Journal of Marriage and the Family 38: 15. [CrossRef]

Stephen, C., and S. John Michael Raj. 2014. U-shaped curve of marital satisfaction: An Indian scenario. Research Horizons 4: 176-83. [CrossRef]

Suzuki, Sawako. 2010. The Effects of Marital Support, Social Network Support, and Parenting Stress on Parenting: Self-Efficacy among Mothers of Young Children in Japan. Journal of Early Childhood Research 8: 40-66. [CrossRef]

Tabachnick, Barbara G., Linda S. Fidell, and Jodie B. Ullman. 2019. Using Multivariate Statistics, 7th ed. Boston: Pearson.

Tavakol, Zeinab, Alireza Nikbakht Nasrabadi, Zahra Behboodi Moghadam, Hamid Salehiniya, and Elham Rezaei. 2017. A Review of the Factors Associated with Marital Satisfaction. Galen Medical Journal 6: 197-207. [CrossRef]

Timmons, Adela C., and Gayla Margolin. 2015. Family Conflict, Mood, and Adolescents' Daily School Problems: Moderating Roles of Internalizing and Externalizing Symptoms. Child Development 86: 241-58. [CrossRef]

Vest, Bonnie M., Sarah Cercone Heavey, D. Lynn Homish, and Gregory G. Homish. 2017. Marital Satisfaction, Family Support, and Pre-Deployment Resiliency Factors Related to Mental Health Outcomes for Reserve and National Guard Soldiers. Military Behavioral Health 5: 313-23. [CrossRef]

Weiss, Susan Pick, and Patricia Andrade Palos. 1988. Diferencias Sociodemográficas En La Satisfacción Marital: El Caso de México. Revista de Psicologia Social 3: 91-97. [CrossRef]

Whisman, Mark A. 2019. Psychopathology and couple and family functioning. In APA Handbook of Contemporary Family Psychology: Applications and Broad Impact of Family Psychology. Washington, DC: American Psychological Association, vol. 2, pp. 3-20.

Whisman, Mark A., Anna L. Gilmour, and Julia M. Salinger. 2018. Marital Satisfaction and Mortality in the United States Adult Population. Health Psychology 37: 1041-44. [CrossRef]

Whisman, Mark A., David A. Sbarra, and Steven R. H. Beach. 2021. Intimate Relationships and Depression: Searching for Causation in the Sea of Association. Annual Review of Clinical Psychology 17: 233-58. [CrossRef] 